\title{
Impact of Development and Efficiency of Financial Sector on Economic Growth: Empirical Evidence from Developing Countries
}

Author: Najia SAQIB, Assistant Professor, Business Administration Department, Prince Sultan University Riyadh, Kingdom of Saudi Arabia,dr.najiasaqib@gmail.com and nsaqib@pscw.psu.edu.sa

This paper analyses the impact of development and efficiency of financial sector on economic growth of a group of selected developing countries using a cross-country data averaged over the period 2005-2009. The results show that the impact of financial sector efficiency on economic growth is significantly positive for developing countries. For a sample of 50 developing countries the effect of financial sector development and financial sector efficiency is positive and highly significant. The sensitivity analysis also shows that the relationship remain positive and significant no matter what combination of the omitted variables are used in the basic model. Thus, our findings support the core idea that development and efficiency of financial sector stimulates economic growth.

Keywords: Financial Development; Financial Efficiency; Economic Growth; Comparative Studies of Countries

JEL Classification: $E_{44} ; F_{43} ; N_{20}, O_{57}$ 


\section{Introduction}

For the last few decades, the relationship between financial depth and economic growth has received serious attention in the literature. The theoretical and empirical studies although substantially advanced in this area but they did not lead to a general consensus on the appearance and direction of the relationship. Thus, the issue still attracts researchers to advance the knowledge in this area.

From a fundamental economic point of view, the growth of financial markets can be attributed to the existence of market frictions that exists in the form of transaction and information costs. Financial intermediaries also play a role in reducing the costs that are associated with savings and investment decisions. Finally, financial markets are expected to contribute to an efficient allocation of available resources that can positively affect economic growth. Acemoglu and Zilibotti, (1997) conclude that financial depth mobilizes and pools savings. It thereby not only fosters capital accumulation but also contributes to a better resource allocation in the economy. This is achieved through economies of scale and overcoming investment indivisibilities.

Greenwood and Smith (1997) develop a model wherein financial markets promote specialization and reduce transaction costs, which lead to productivity gains that translate into higher growth. Financial institutions also reduce liquidity risk as they allow the transformation of liquid financial assets (that are desirable by the savers) into long-term capital investments. Furthermore financial markets modernize information costs on investment opportunities and thus improve the allocation of capital.

Shleifer and Vishny (1996) confirmed that financial intermediaries that function efficiently improve the monitoring of investment activities and enhance corporate governance. Owing to the existence of market frictions such as high transactions costs and information asymmetries, diffused shareholders may be prevented from exercising adequate control over the managers of the firms. The problem of corporate governance can be ameliorated by smooth functioning of financial arrangements. In general, the above mechanisms suggest that financial development should have a significant positive effect on economic growth as it fosters capital 
accumulation and leads to productivity gains thanks to a better allocation of resources $^{1}$. Through the expansion and sophistication of financial institutions, the amount and quality of the supply of financial services increases, and this in turn promotes economic growth. However, the view that financial development is a key determinant of economic growth has been challenged from different angles throughout the past few decades.

First, it was pointed out that, from a theoretical perspective, improvements in resource allocation would not necessarily lead to higher economic growth. In fact, under certain conditions, higher returns on savings that result from financial sector development can reduce savings rates to such an extent that overall growth slows ${ }^{2}$. Similarly, if development of the financial sector lowers the liquidity constraints of individuals, the overall savings rate may decline, leading to weaker economic growth (see Jappelli and Pagano, 1994). Secondly, a number of economists support the so-called "demand-following hypothesis" (see, Ireland, 1994). According to this hypothesis, causality between the two phenomena runs the other way, namely from economic growth to financial development: in the process of a growing economy, individuals demand more and better financial services, which then fosters financial development. A third group of economic researchers deny a quantitatively important causal relation between financial development and economic growth. Instead, they regard them as largely independent phenomena. According to this view, financial development may help to predict economic growth as financial markets develop in anticipation of economic activity. However, finance is not regarded as a fundamental cause of economic growth. Finally, as highlighted by, among others, Greenwood and Smith (1997), causality between the two variables might run in both directions. That is, financial development and economic growth may mutually cause each other ${ }^{3}$.

\footnotetext{
${ }^{1} \mathrm{n}$ the literature, this direction of causality is often referred to as the "supply-leading hypothesis". 2 The overall impact of higher returns on the savings rate depends on the relative strength of the implied income and substitution effects that work in different directions

3 This is known as "stage of development hypothesis". Supply-leading financial development is a key determinant of real economic growth in the early stages of development, whereas at later stages financial development mainly follows real growth.
} 
Based on the review of above theoretical debate, this paper addresses research question: whether financial sector developments and financial sector efficiency promotes economic growth or retards it.? To answer this question, we use two different indicators of financial sector development and one indicator of financial sector efficiency to test the relationship for a sample of 50 developing countries for a data averaged over the period 2005-2009. To check the robustness of the results a simple sensitivity analysis is also performed.

The remainder of the paper is organized as follows. Section II discusses the previous empirical studies on the subject. Section III describes our simple model and discusses the estimation results. Section IV presents sensitivity analyses and section $\mathrm{V}$ gives conclusion and policy implications.

\section{Empirical Literature}

A large number of empirical studies have tried to assess the qualitative and quantitative impact of financial development on economic growth by using different types of econometric approaches and a variety of indicators to measure financial development. In a seminal study, King and Levine (1993b) analyzed cross-country data for 80 countries over the period 1960-1989. They use four different indicators to measure financial development ${ }^{4}$. Controlling for other variables that affect long-run growth, they found that different financial indicators were strongly and robustly correlated with economic growth. They also showed that the initial level of financial depth was a good predictor of subsequent rates of economic growth even after controlling for other growth-enhancing factors.

Levine and Zervos (1998) extend the empirical analyses by studying the empirical relationship between several measures of stock market development, banking development and long run economic growth. They found that both the initial level of stock market liquidity (measured by the

\footnotetext{
${ }^{4}$ These indicators were (i) the ratio of liquid liabilities to GDP; (ii) ratio of deposit money bank assets to total assets; (iii) the ratio of non financial private sector credit to total credit; and (iv) ratio of claims on the non financial private sector to GDP.
} 
turnover ratio ${ }^{5}$ ) and the initial level of banking development (measured by bank credit to the private sector as a ratio of GDP) were robustly correlated with future economic growth. They concluded that financial development and economic growth have strong positive link and that financial factors are an integral part of the growth process.

Later, Levine, Loayza, and Beck (200o) estimate a generalized method of moments (GMM) equation with panel data. Concerning the measurement of financial development, they introduced the new indicator "private credit", which is defined as the value of credits by financial intermediaries to the private sector divided by GDP. Financial intermediaries comprise both deposit money banks and other financial institutions. Levine, Loayza, and Beck (200o) found evidence of a strong link between financial development and economic growth. Their results indicated that the evolution of private credit had a particularly large impact on the growth performance in their sample.

$\mathrm{Xu}$ (2000) use a multivariate vector autoregressive approach to examine the effects of permanent financial development on domestic investment and output in 41 countries between 1960 and 1993. The results showed that financial development is important to GDP growth and that domestic investment is an important channel through which financial development affects economic growth. Furthermore, many countries were able to turn the short-term negative effects to long term positive effects, and all these results were robust.

In a recent study Rioja and Valev (2004) investigate the channels through which financial development influence economic growth in a panel of 74 countries during 1961-1995. They found that finance has a strong positive influence on productivity growth primarily in more developed countries. In less developed countries, the effect of finance on output growth occurs primarily through capital accumulation.

In addition to cross-country and panel studies, a substantial amount of literature has employed time-series techniques to investigate the financegrowth relationship. Using basically Granger-type causality tests and vector

\footnotetext{
${ }^{5}$ Turnover ratio was measured as value of the trades of domestic shares on domestic exchange divided by the value of listed domestic share.
} 
autoregressive procedures, the majority of these studies provide support for the hypothesis that causality runs from financial development to growth.

Rousseau and Wachtel (1998) conduct a time-series tests of financial development and growth for five countries using a measure of financial development that includes the assets of both banks and non-banks. They concluded that the dominant direction of causality runs from financial development to economic growth. Khan et al. (2005) test the relationship between financial development and economic growth for Pakistan over the period 1971-2004, using Autoregressive Distributed Lag (ARDL) technique. The results of the study showed that in the long-run financial depth and real interest rate exert positive impact on economic growth. However, the relationship between growth and financial development is though positive but remained insignificant in the short-run. They concluded that growth is an outcome of financial development.

Recently, Waheed and Younus (2009) analyze the long run relationship between financial development and growth in Pakistan using a time series data for the period 1971-2006. They concluded that there exist a long run robust relationship between financial development and economic growth in the country.

Overall, recent empirical evidence from cross-country, panel and time-series studies suggests that financial development is an important determinant of economic growth. However, the impact may be nonlinear. This could be especially true in countries with very low institutional quality, where financial deepening may not translate into higher economic growth.

\section{Model and Results}

Thus, based on the theoretical discussion, empirical studies, data availability and the need to conserve degrees of freedom, only three variables are chosen for our basic model to explain the variation in per capita income. The basic equation is:

$$
Y=\beta o+\beta_{1} X+\beta_{2} H+\beta_{3} F D+\varepsilon t
$$

Where $\mathrm{Y}$ represent economic growth. We have followed standard practice (Roubini and Sala-i-Martin 1992, and King and Levine 1993a, b) to use real GDP per capita GDP as an indicator for economic growth. $\mathrm{X}$ is a set 
of variables always included in the regression. In our model we include ratio of gross fixed capital formation to GDP as a proxy for physical capital (IGDP). $\mathrm{H}$ is a subset of variables identified by the literature as potentially important explanatory variables for growth. Here we use combined primary, secondary and tertiary gross enrolment ratio (ENRL) as a proxy for human capital. FD denotes variables of interest and $\varepsilon t$ denotes the error term.

Several indicators of financial development have been proposed in the literature. Of course, different indicators will proxy different aspects of the relationship between the financial development and economic performance. The most frequently used conventional proxy to measure the degree of financial sectors development is the ratio of a less liquid monetary asset, normally $\mathrm{M}_{2}$ or $\mathrm{M}_{3}$, to the level of nominal GDP. Therefore, the first proxy of the degree of financial deepening is the ratio of the stock of broad money (M2) to GDP (M2GDP). This indicator is used, for example, by King and Levine (1993b), Darrat (1999), Nashashibi et al. (2001). Throughout the process of development, the ratio $\mathrm{M} 2 \mathrm{GDP}$ has a tendency to rise as access to banking and alternative instruments of store of value (investment and savings) spread. Therefore, an increase in this variable signifies a larger financial sector. However, as markets mature, the ratio M2/GDP tends to decline as other financial instruments not included in M2 are developed and become increasingly available.

Recent theoretical and empirical research has demonstrated that an effective mobilization of domestic savings and an efficient allocation of resources depend on the extent to which the private sector can obtain loans. It is argued that loans extended to the private sector promote investment and productivity growth to a much greater extent than do credits to the public sector. An increase in the ratio of private credit to GDP (PCGDP) can be interpreted as a sign of more financial services and thus as an improvement in financial intermediation. The recent empirical literature on the role of financial intermediation in economic development has highlighted the suitability of this indicator to measure the level of financial sector development (see, for example, De Gregorio and Guidotti (1995); Demetriades and Hussein (1996); Levine and Zervos (1998); and Beck and Levine (2004)). In addition, as De Gregorio and Guidotti (1995) argued, 
private credit has an obvious advantage over measures of monetary aggregates such as $M_{1}, M_{2}$, and $M_{3}$ since it more precisely represents the actual quantity of funds directed to the private sector. Thus, our second measure of financial sector development is the ratio of private credit to GDP (PCGDP).

The level of interest rates affect people's behavior by affecting economic decisions with regard to how much people are willing to save, and how much businesses are willing to invest. An informative indicator of a banking system's success in intermediating funds between savers and investors is the spread between deposit and lending rates (De Nicolo et al. 2003). Thus spread (SPRD) can be used as an indicator of the efficiency of the financial sector. We expect a negative sign of this coefficient in our model, because a fall in the value of this indicator represents an increase in efficiency and may results higher economic growth.

Hence, in this study we include two indicators namely M2GDP and PCGDP as a measure of financial sector development and one indicator SPRD as a measure of financial sector efficiency to proxy FD variable in our model. We perform the analysis a cross-section of fifty developing countries. The data that have been used in this analysis are annual covering the period from 2005-2009. This is the latest period up to which all data are available in complete form. The data come from the World Bank's World Development Indicators database. The selection of countries is based on data availability on all variables from this source.

Countries are grouped into three groups: lower, lower-middle and upper-middle depending on the relative ranking of their income per capita in the middle of the sample period ${ }^{6}$. We use several income groups since much of the policy literature discusses country difference in terms of developing countries ${ }^{7}$. For further motivation, Table 1 reports

\footnotetext{
${ }^{6}$ According to the income classification by World Bank, Economies are divided among income groups according to 2006 gross national income (GNI) per capita, calculated using the World Bank Atlas method. The groups are: low income, $\$ 1,025$ or less; lower middle income, $\$ 1,026$ $\$ 4,035$ and upper middle income, $\$ 4,036$ - $\$ 12,475$.

${ }^{7}$ Low-income and middle-income economies are sometimes referred to as developing economies. The use of the term is convenient; it is not intended to imply that all economies in the group are experiencing similar development or that other economies have reached a preferred or final stage of development.
} 
macroeconomic and financial indicators for the sub-samples of countries, which we later use in the econometric analysis. Table 1 shows that output growth was substantially slower in low-income countries: $5.61 \%$ in lowerincome, $4.58 \%$ in lower middle-income and $4.39 \%$ in upper middle-income. Investment to GDP ratio accounts is $16.45 \%$ in lower-income, $\mathbf{2 2 . 0 8 \%}$ in lower middle-income and $\mathbf{2 2 . 0 3} \%$ in upper middle-income countries.

This difference prompts us to examine whether finance has different channels for influencing economic growth at various levels of development. Table 1 report the average values of the two financial sector development variables (M2 to GDP and Private Credit to GDP ratio) in the three income groups. We also analyze the financial sector efficiency variable (Spread), which has high percentage in lower-income groups. This indicates that if we reduce spread (that is, increase the efficiency of the financial sector), it may have positive effect on economic growth of low income countries. The data shows that the human capital level (Enrolment) is lower in low-income countries.

Table 1: Summary of Data for Different Income-Groups

\begin{tabular}{|l|c|c|c|c|}
\hline \multicolumn{1}{|c|}{ Variables } & $\begin{array}{c}\text { Lower Income } \\
\text { Group }\end{array}$ & $\begin{array}{c}\text { Lower Middle Income } \\
\text { Group }\end{array}$ & $\begin{array}{c}\text { Upper Middle Income } \\
\text { Group }\end{array}$ & $\begin{array}{c}\text { Full } \\
\text { sample }\end{array}$ \\
\hline (2005-2009) & $\mathbf{( 2 0 0 5 - 2 0 0 9 )}$ & (2005-2009) & $\begin{array}{c}\text { (2005- } \\
\text { 2009) }\end{array}$ \\
\hline $\begin{array}{l}\text { Investment to GDP } \\
\text { Ratio }\end{array}$ & 16.45 & 22.08 & 22.03 & 21.06 \\
\hline Enrolment & 52.13 & 71.64 & 77.27 & 74.25 \\
\hline M2 to GDP Ratio & 27.12 & 46.58 & 52.45 & 56.6 \\
\hline $\begin{array}{l}\text { Private Credit to GDP } \\
\text { Ratio }\end{array}$ & 17.53 & 33.14 & 44.26 & 51.68 \\
\hline SPREAD & 12.05 & 9.23 & 8.81 & 8.06 \\
\hline Trade Openness & 65.55 & 86.23 & 93.50 & 90.67 \\
\hline Inflation & 8.28 & 8.24 & 8.45 & 6.55 \\
\hline FDI to GDP Ratio & 1.84 & 2.98 & 5.44 & 3.89 \\
\hline Real GDP growth & 5.61 & 4.58 & 4.39 & 4.54 \\
\hline $\begin{array}{l}\text { Real Per capita } \\
\text { Income growth }\end{array}$ & 3.19 & 3.55 & 3.51 & 3.25 \\
\hline
\end{tabular}

Note: (i) SPRD = lending rate - deposit rate. (ii) The number of 50 developing countries in full sample.

Source: World Development Indicators (2012). 
Table 2 shows the regression results of three basic models for a sample of 50 countries. It is clear from table 1 that our first indicator of financial development (M2GDP) included in basic model 1 has the expected positive sign and is highly significant. The high value of adjusted R2 represents that model is also good fit. Our second measure of financial sectors' development (PCGDP) in the basic model 2 has the expected positive sign and is highly significant. It is clear that PCGDP variable has much stronger effect than M2GDP. Basic model 3 shows that the measure of financial sector efficiency (SPRD) has expected sign and is highly significant. Thus, reduction in (SPRD) that is, an increase in financial sector efficiency has significant positive effect on economic growth. Hence, all models show that financial sector development and financial sector efficiency promote economic growth.

Table 2: Summary of Results for a Full Sample of Fifty Countries

\begin{tabular}{|c|c|c|c|c|c|c|c|c|c|}
\hline \multirow[t]{2}{*}{ Variables } & \multicolumn{3}{|c|}{$\begin{array}{c}\text { Basic Model } \\
\text { I }\end{array}$} & \multicolumn{3}{|c|}{$\begin{array}{c}\text { Basic Model } \\
\text { II }\end{array}$} & \multicolumn{3}{|c|}{$\begin{array}{c}\text { Basic Model } \\
\text { III }\end{array}$} \\
\hline & Coeff. & t-stats & Prob. & Coeff. & t-stats & Prob. & Coeff. & t-stats & Prob. \\
\hline Constant & 2.028 & 12.228 & 0.000 & 2.221 & 14.738 & 0.000 & 2.2369 & 9.557 & 0.000 \\
\hline IGDP & 0.014 & 2.913 & 0.00 & 0.014 & 3.322 & 0.001 & 0.015 & 2.798 & 0.007 \\
\hline ENRL & 0.017 & 9.376 & 0.000 & 0.014 & 8.094 & 0.000 & 0.019 & 8.230 & 0.000 \\
\hline M2GDP & 0.002 & 3.934 & 0.002 & ------ & ------ & ------ & ------ & ------ & ----- \\
\hline PCGDP & ------ & ------- & ----- & 0.003 & 5.548 & 0.000 & ------- & ------- & ------י \\
\hline SPRD & ------- & ------ & ------- & ------ & ------ & ------ & -0.021 & -4.042 & 0.000 \\
\hline Adjusted- $\mathrm{R}^{2}$ & 0.678 & ------- & ------ & 0.678 & ------- & ------- & 0.577 & ------- & ----- \\
\hline DW Stat & 2.132 & ------ & ------- & 2.132 & ------ & ----- & 2.355 & ----- & ----י- \\
\hline F-Statistics & 69.088 & ------- & 0.000 & 69.088 & ------ & 0.000 & 36.141 & ----- & 0.000 \\
\hline
\end{tabular}

Note: (i) SPRD = lending rate - deposit rate. (ii) The number of countries is 50 in basic model I \& II and 35 in basic model III.

Source: Author estimation. 
Hence, all model models show that financial sector development and financial sector efficiency promote economic growth of the selected developing countries.

\section{Sensitivity Analysis}

Since many factors are associated with economic growth, the empirical results on the relationship between one factor and economic growth is not always robust. Therefore, it is necessary to examine the robustness of the results reported in section 3. The question of how much confidence could be placed on the conclusions was addressed by Levine and Renelt (1992) that use a modified version of the Extreme Bond Analysis (EBA) originally developed by Leamer (1985). A slightly modified version of EBA approach is used, hereby, considering the following model $^{8}$.

$$
Y_{t}=\beta_{0}+\beta_{1} I_{t}+\beta_{2} M_{t}+\beta_{3} Z_{t}+\xi_{t}
$$

Where ' $\mathrm{Y}$ ' is the real GDP per capita, 'I' is a set of variables that are commonly included in the regression, ' $M$ ' is the variable of particular interest and ' $\mathrm{Z}$ ' is a set of variables chosen from a pool of variables and $t$ is the white noise error term. In our case, ' $I$ ' or basic variable is the ratio of investment to GDP $(\mathrm{IGDP})^{9}$ ), the ' $\mathrm{M}$ ' variable is the variable of interest, which is the financial sector development and financial sector efficiency. The 'Z' variables are selected as follows: (i) openness (OPE), (ii) the ratio of Foreign Direct Investment to GDP (FDI), (iii) Inflation (INF), and (iv) life expectancy at birth (LEXP) ${ }^{10}$.

\footnotetext{
${ }^{8}$ The EBA involves varying the $\mathrm{Z}$ variable to determine whether the coefficient on the focus variable, $M$ is consistently significant and of the same sign when right hand side variables change. 9 Levine \& Renalt (1992) and Temple (1999) have included this variable in their regression ${ }^{10}$ Levine \& Renalt (1992) used inflation and openness, Hermes \& Lensink (2003) and Alfaro et al. (2004) used FDI and Barro (1991) used mortality rate in their growth regression.
} 
Table 5: Results of Sensitivity Analysis

\begin{tabular}{|l|c|c|c|c|c|c|}
\hline & \multicolumn{5}{|c|}{ Modified Model I } \\
\hline Variables & Coef. & t-stat & prob & Adj.R & DW & F-stat \\
\hline OPEN & 0.004 & 4.496 & 0.000 & 0.230 & 1.821 & 10.667 \\
\hline INF & 0.004 & 4.059 & 0.000 & 0.228 & 1.835 & 10.554 \\
\hline FDI & 0.004 & 4,65 & 0.000 & 0.229 & 1.984 & 9.916 \\
\hline LEXP & 0.001 & 2.099 & 0.038 & 0.493 & 1.928 & 32.427 \\
\hline Basic Model I & 0.002 & 3.934 & 0.000 & 0.608 & 2.175 & 51.293 \\
\hline Basic Model II & - & - & - & - & - & - \\
\hline & & & \multicolumn{7}{|c|}{ Modified Model II } & \\
\hline Variables & Coef. & t-stat & prob & Adj.R & DW & F-stat \\
\hline OPEN & 0.005 & 8.290 & 0.000 & 0.459 & 1,77 & 28.507 \\
\hline INF & 0.006 & 7.946 & 0.000 & 0.457 & 1.827 & 28.251 \\
\hline FDI & 0.005 & 8.568 & 0.000 & 0.477 & 1.944 & 28.469 \\
\hline LEXP & 0.003 & 5.731 & 0.000 & 0.606 & 1.883 & 50.856 \\
\hline Basic Model I & - & - & - & - & - & - \\
\hline Basic Model II & 0.003 & 5.548 & 0.000 & 0.678 & 2.132 & 69.088 \\
\hline
\end{tabular}

Note: In case of FDI the countries included in the sample are 47.

Source: Author's estimation.

The results of sensitivity analysis are shown in the Table 5 for a full sample of 50 developing countries. It is clear that our focus variable (financial sector development) is significant and positive in both models no matter what combination of other variables are included in the modified models. Thus, it is confirmed that financial sector development has robust positive effect on economic growth of the developing countries. 


\section{Conclusions}

This paper offers a broad analysis of the effect of development and efficiency of financial sector on economic growth for a large cross section of countries. We also did the same analysis for a group of developing countries. The evidence presented in this paper provides strong and robust support to the view that financial sector development is crucial for economic growth and the efficiency of the financial sector is potentially important for the long term growth performance of the developing countries. Given this positive relation, the importance of financial sector development should not be underestimated and has to be one of the main strategies to achieve sustainable economic growth in the long term. Building sound and stable financial sectors requires; liberalization of the financial system, adoption of the internationally acceptable codes and standards, strengthening of prudential regulation and supervision and training of the staff to manage and regulate these institutions.

\section{References}

[1] Acemoglu, D., Zilibotti, F., "Was Prometheus Unbound by Chance? Risk, Diversification, and Growth", Journal of Political Economy, Vol. 105, No 4, 1997, pp.709-51.

[2] Alfaro, L., Chanda, A, Kalemli-Ozcan, S., Sayek, S., "FDI and Economic Growth, the Role of Local Financial Markets", Journal of International Economics, Vol. 64, 2004, pp.89-112.

[3] Barro, R. J., "Growth in a Cross Section of Countries", Quarterly Journal of Economics, Vol. 106, No 2, 1991, pp.407-43.

[4] Beck, T., Levine, R., "Stock Markets, Banks, and Growth: Panel Evidence", Journal of Banking \& Finance, Vol. 28, 2004, pp.423-42.

[5] De Gregorio, J., Guidotti, P. E., "Financial Development and Economic Growth", World Development, Vol. 23, No 3, 1995, pp.43338.

[6] De Nicolo G., Geadah, S., Rozhkor, D., "Poorly Developed Financial Systems in the CIS-7 Countries may Jeopardize their Sustained Growth", Finance and Development, 2003, pp.42-45. 
[7] Demetriades, P. O., Hussein, K. A., "Does Financial Development cause Economic Growth? Time-series Evidence from 16 Countries”, Journal of Development Economics, Vol. 51, 1996, pp.387-411.

[8] Greenwood, J., Smith, B., "Financial Markets in Development, and the Development of Financial Markets", Journal of Economic Dynamics and Control, Vol. 21, 1997, pp.145-81.

[9] Hermes, N., Lensink, R., "Foreign Direct Investment, Financial Development and Economic Growth", Journal of Development Studies, Vol. 40, No 1, 2003, pp.142-63.

[10] Ireland, P. N., "Money and Growth: An Alternative Approach", American Economic Review, Vol. 84, No 1, 1994, pp.47-65.

[11] Jappelli, T., Pagano, M., "Saving, Growth and Liquidity Constraints", Quarterly Journal of Economics, Vol. 109, No 1, 1994, pp.83-109.

[12] King, R. G., Levine, R., "Finance, Entrepreneurship, and Growth: Theory and Evidence", Journal of Monetary Economics, Vol. 32, No 3, 1993a, pp. 513-42.

[13] King, R. G., Levine, R., "Finance and Growth: Schumpeter Might Be Right", Quarterly Journal of Economics, Vol. 108, No 3, 1993b, pp.717-737.

[14] Khan, M. A., Qayyum, A., Sheikh, S. A., "Financial Development and Economic Growth: the Case of Pakistan", Pakistan Development Review, Vol. 44, No 4, 2005, pp.819-37.

[15] Leamer, E. E., "Sensitivity Analysis Would Help", American Economic Review, Vol. 75, No 3, 1985, pp.308-13.

[16] R., Renelt, D., "Sensitivity Analysis of Cross-Country Growth Regressions", American Economic Review, Vol. 82, No 4, 1992, pp.942-63.

[17] Levine, R., Zervos, S., "Stock Markets, Banks, and Economic growth", American Economic Review, Vol. 88, No. 3, 1998, pp.537-58.

[18] Levine, R., Loayza, N., Beck, T., "Financial Intermediation and Growth: Causality and Causes", Journal of Monetary Economics, Vol. 46, 2000, pp.31-77. 
[19] Rioja, F., Valev, N., "Finance and the Sources of Growth at Various Stages of Economic Development", Economic Inquiry, Vol. 42, No 1, 2004, pp. 127-140.

[20] Roubini, N., Sala-i-Martin, X., "Financial Repression and Economic Growth", Journal of Development Economics, Vol. 39, 1992, pp.5-30.

[21] Rousseau, P. L., Wachtel, P., "Financial Intermediation and Economic Performance: Historical Evidence from Five Industrialized Countries", Journal of Money, Credit and Banking, Vol. 30, No 4, 1998, pp.65778.

[22] Shleifer, A., Vishny, R. W., "Survey of Corporate Governance, National Bureau of Economic Research", NBER Working Paper 5554. 1996.

[23] Temple, J., "The New Growth Evidence", Journal of Economic Literature, Vol. 37, No 1, 1999, pp.112-56.

[24] Waheed, A., Najia, Y., "Financial Development and Economic Growth: Empirical Evidence from Pakistan”, Asian Economic Review, Vol. 51, No 1, 2009, pp.33-42.

[25] World Bank, World Development Indicators. Washington D.C. The World Bank, 2008.

[26]Xu, Z., "Financial Development, Investment, and Economic Growth", Economic Inquiry, Vol. 38, 2000, pp.331-44. 